\title{
Non-frail elderly people and their license to drive motor vehicles
}

\author{
Idosos não frágeis e a habilitação para dirigir veículos automotores \\ Ancianos no frágiles y la habilitación para conducir vehículos automotores
}

\begin{abstract}
Maria Helena Lenardt', Ana Carolina Kozlowski Cordeiro Garcia', Maria Angélica Binotto', Nathalia Hammerschmidt Kolb Carneiro', Tânia Maria Lourenço', Clovis Cechinel'
\end{abstract}

' Universidade Federal do Paraná, Postgraduate Program in Nursing Curitiba. Paraná, Brazil.

How to cite this article:

Lenardt MH, Garcia ACKC, Binotto MA, Carneiro NHK, Lourenço TM, Cechinel C. Non-frail elderly people and their license to drive motor vehicles. Rev Bras Enferm [Internet]. 2018;71(2):350-6. DOI: http://dx.doi.org/10.1590/0034-7167-2016-0675

\section{Submission: 02-14-2017 Approval: 05-03-2017}

\section{ABSTRACT}

Objective: to analyse the link between the non-frailty condition and the results of driving license for elderly people to drive motor vehicles. Method: cross-sectional study with data collection in the sample period from August 2015 to March 2016 . Study performed with 347 elderlies ( $\geq 60$ years). Results: 180 (51.9\%) of the participants were classified as non-frail. 48 (26.7\%) of them were considered capable to drive, 121 (67.2\%) capable to drive with restrictions and 11 (6.1\%) temporarily uncapable. No significant relation was found between the non-frailty conditions and the results of the motor vehicles driving license study $(p=0.557)$. Conclusion: The absence of physical frailty does not necessarily points out that the elderly are able to drive motor vehicles. Tracking the frailty subsidizes preventive interventions, which seek to interfere positively in the act of driving. This is an unprecedented study in nursing and it highlights an essential field for the performance of gerontological nursing.

Descriptors: Frail Elderly; Geriatric Nursing; Driver's License Exam; Vehicle Driving; Elderly.

\section{RESUMO}

Objetivo: analisar a associação entre a condição de não fragilidade física e os resultados da habilitação dos idosos para dirigir veículos automotores. Método: estudo transversal com coleta de dados no período amostral de agosto de 2015 a março de 2016 e realizado com 347 idosos ( $\geq 60$ anos). Resultados: dos participantes, 180 (51,9\%) foram classificados como não frágeis. Destes, 48 $(26,7 \%)$ foram considerados aptos para dirigir, $121(67,2 \%)$ aptos com restrição e $11(6,1 \%)$ inaptos temporariamente. Não houve associação significativa entre a condição de não fragilidade física e os resultados da habilitação para dirigir veículos automotores $(p=0,557)$. Conclusão: a ausência de fragilidade física não indica, necessariamente, que o idoso está apto para dirigir veículos automotores. O rastreamento da fragilidade subsidia intervenções preventivas, que visam interferir de maneira positiva no ato de dirigir. O estudo é inédito na enfermagem e aponta um local indispensável para atuação da enfermagem gerontológica.

Descritores: Idoso Fragilizado; Enfermagem Geriátrica; Exame para Habilitação de Motoristas; Condução de Veículo; Idoso.

\section{RESUMEN}

Objetivo: analizar la asociación entre la condición de no fragilidad física y los resultados de la habilitación de ancianos para conducir vehículos automotores. Método: estudio transversal con recolección de datos en el período de muestreo de agosto de 2015 a marzo de 2016 y realizado con 347 ancianos ( $\geq 60$ años). Resultados: De los participantes, 180 (51,9\%) fueron clasificados como no frágiles. De estos, 48 (26,7\%) fueron considerados aptos para conducir, 121 (67,2\%) aptos con restricción y $11(6,1 \%)$ inaptos temporalmente. No hubo asociación significativa entre la condición de no fragilidad física y los resultados de la habilitación para conducir vehículos automotores $(p=0,557)$. Conclusión: La ausencia de fragilidad física no indica necesariamente que el anciano está apto para conducir vehículos automotores. El rastreo de la fragilidad subsidia intervenciones preventivas, que apuntan a interferir de manera positiva en el acto de conducir. El estudio es inédito en la enfermería y apunta un local indispensable para la actuación de la enfermería gerontológica.

Descriptores: Ancianos Fragilizados; Enfermería Geriátrica; Examen para la Habilitación de Conductores; Conducción de Vehículos; Ancianos.

\section{CORRESPONDING AUTHOR Maria Angélica Binotto E-mail: manbinotto@yahoo.com.br}




\section{INTRODUCTION}

Statistical data issued by traffic agencies have shows an increase in the number of elderly drivers. In Brazil, the Departamento Nacional de Trânsito (DETRAN) registered 3.2 million drivers over 61 years old in 2005. This number increased to 3.6 million in 2012.

In 2015, a national survey counted 60.7 million people with National Driver's License and 4.4 million qualified drivers in the state of Paraná(2). Considering the total number of drivers in this state, 1,237.471 were $\geq 55$ years old, with more men (950.886) than women $(286.585)^{(3)}$. In the city of Curitiba, $51.2 \%$ of the population are drivers and have their driver's license. Data from 2011 by the Batalhão da Polícia de Trânsito (BPTRAN) showed that $16 \%$ of the city's drivers are over $55^{(4)}$.

The act of driving is strictly connected to independence and control over one's own life. It is through driving that many elderlies manage to fulfil their social role. On the other hand, it is a very complex activity that demands physical, cognitive, behavioural and sensory-perceptive abilities.

The aging process is often marked by gradual loss of strength and reduced physical function. This process can jeopardize elderly drivers already weakened. Researchers in the field of geriatrics and gerontology have dedicated their efforts to propose, develop and introduce preventive interventions against conditions that determine/ lead the elderly to disabling situations ${ }^{(6)}$. In this context, physical frailty has been recognized as one of the disabling conditions. It interferes in the deregulation of many body systems and increases vulnerability to adverse events ${ }^{(7)}$.

The thorough assessment for elderly candidates to their National Driver's License or its renewal is a needed measure, that identifies possible risks to which those are subject when driving motor vehicles. The present study considers physical frailty as a possible instrument, which can furnish a proper evaluation and, consequently, a safer vehicle driving for elderlies.

Physical frailty is a "medical symptom with multiple causes and contributions/ determinants that is characterized by decreased strength and endurance and reduced physiological function, increasing the vulnerability of the individual and developing greater dependence and/ or death."(8)

A group of researchers proposed the frailty phenotype by evaluating 5 measurable components: unintentional loss of weight, self-report of fatigue or exhaustion, manual grip strength, walking speed and physical exercises reduction. Individuals who show 3 or more criteria represent frailty; 1 or 2 pre-frailty. No changes in those components represent non-frailty ${ }^{(9)}$.

A systematic reviewed study performed an overview of surveys on evaluation and screening instruments that determine the ability of elderlies to drive. Sixty four studies were examined. Results pointed out that a single tool that evaluates cognition, vision, perception or individual physical ability is insufficient to determine their ability to drive. Diverse assessment tools should be used and directed to the specific clinical conditions of each elderly person ${ }^{(10)}$. However, the existing evaluation is the same for all candidates, regardless of age or specific conditions, such as the frailty syndrome.

There is little study in the literature about the relation between physical frailty in elderly people and the driving of motor vehicles. Given the increase in the number of drivers over $60^{(1)}$ it is of utmost importance to deepen the studies on physiological changes inherent to aging (which directly affect the performance of driving) and on the area entirely.

Frailty and motor vehicle driving is an unprecedented study in the gerontological nursing field. The present study is part of the project entitled: "Frailty in the elderlies and their $\mathrm{Na}$ tional Driver's License". We hope the results provide scientific evidence to subsidize and propose initiatives and specific interventions for the elderlies in the context of driving.

Objective: to analyse the link between the non-frailty condition and the results of driving license for elderly people to drive motor vehicles.

\section{METHOD}

\section{Ethical aspects}

This research project is inserted in a thematic project, entitled "Frailty in the elderlies and their National Driver's License," and it received a favorable opinion. The ethical principles of voluntary and consensual participation were observed in accordance with the recommendations present in Resolution $n^{\circ} .466$ of the Conselho Nacional da Saúde, from December $12,2012^{(11)}$.

\section{Planning and period of study}

This is a quantitative, cross-sectional study carried out in traffic clinics accredited for the physical and mental tests and/ or psychological evaluation for driving motor vehicles, in the city of Curitiba, state of Paraná (PR). It was carried out between June 2015 and September 2016.

\section{Study site}

This research was performed in 11 traffic clinics according to the following inclusion criteria: to be accredited to perform physical and mental ability; to conduct psychological evaluation for driving motor vehicles. Exclusion criteria: not to own proper space to perform the tests.

The traffic clinics were selected through a simple random ballot from a total of 54 clinics. All of them had the same chances to be a part of the study. After the ballot, the clinics were classified with increasing numbers and letters, from C1 to C54. From this order, they were evaluated using the inclusion and exclusion criteria.

\section{Population and sample}

The sample was collected during August 2015 and March 2016. In this period, 419 elderly people were recruited to participate in the study. 43 of them did not accept to take part in the study and 29 were excluded due to their low cognitive score in the Mini-Mental State Examination (MMSE). Overall, 347 elderlies participated in this study.

The cut-off scores for MMSE, according to educational level, were: 13 points for the illiterate, 18 points for low education level (1-4 incomplete education years) and average education (4-8 incomplete education years) and 26 for high education level (8 or more years) ${ }^{(12)}$. 
The following inclusion criteria were established for the elderlies: to be $\geq 60$ years old, scheduled for driving license tests in one of the accredited clinics by the Traffic Agency of Paraná (PR) State; present low cognitive score at MMSE. Exclusion criteria: to present diseases, problems and physical symptoms that, for any reason, would prevent the application of surveys and the performance of tests.

The distribution and scheduling of the elderlies for physical and mental ability tests in the traffic clinic are performed by the executive Traffic Agency of Paraná State. These procedures are under the Decree n. ${ }^{\circ} 303 / 2015-D^{(13)}$, which guarantees the impartial distribution of physical and mental ability tests and/ or psychological evaluation, by means of mandatory and impersonal equitable division. This obeys the criteria regarding geographic distribution, according to the limits of the circumscription in which the clinic is accredited. In order to achieve homogeneity in the collected data and to reduce bias, an assessment of 35 elderlies was conducted in each of the clinic. Once the approval for 35 elderly people was obtained, the collection was then held at the next ballot clinic.

\section{Study protocol}

Data collection was carried out through the application of a structured survey, tests for physical frailty evaluation and information obtained in the form of the Registro Nacional de Condutores Habilitados (RENACH).

For the structured survey, personal, clinical and driving characteristics were considered, with the following variables of interest for the study: age, sex, education, use of medicines, use of glasses, driving during the night and the day, the city centre or roads and traffic accidents with drivers over 60 years old.

For the physical frailty evaluation we have used the phenotype proposed by Fried et $\mathrm{al}^{(9)}$ : "The manual grip strength was measured with a Jamar ${ }^{\circledR}$ hydraulic dynamometer. After adjusting for sex and body mass, those in the lowest quintile value were considered frail elderly people"(9).

To assess the component of walking speed, the participant walked for 4.6 meters straight, regular steps. The time was measured in seconds. After adjusting for sex and body mass, those in the lowest quintile value were considered frail elderly people ${ }^{(9)}$.

Unintentional loss of weight was evaluated through 2 questions: Have you lost weight in the last 12 months? If the answer were yes, we would ask: how many kilograms? The elderly should have had an unintentional loss of weight $\geq$ $4.5 \mathrm{~kg}$ in the last 12 months to be considered frail.

To assess the component fatigue/ exhaustion, items 7 and 20 from the Scale of Center for Epidemiological Studies - Depression (CES-D) were used. The answers were separated from 0 to 3, regarding the frequency. The answers 2 and 3 for these questions classified the participant as frail.

To assess the physical exercise frequency the Minnesota Leisure Activity Questionnaire was applied and validated for Brazilian elderly people ${ }^{(14)}$. After adjusting for sex and body mass, those in the lowest quintile value were considered frail elderly people ${ }^{(9)}$.

In the RENACH form, the medical expert in traffic issued the final results of the elderly assessment in the physical and mental ability to drive. According to the Resolution of Conselho
Nacional de Trânsito $n^{\circ}$ 425, from November 27, 2012(15), the result considers the candidate: "capable", "capable with restrictions", "temporarily uncapable" or "uncapable". In the result "capable with restrictions", the restrictions have been specified.

\section{Results analysis and statistics}

We have organized the data in the Excel 2007 program, under double checking. Later, the same database was checked by a third person in order to reduce possible errors. We used descriptive statistics and non-parametric test of association among categorical variables (Qui-quadrado). Numbers such as $p \leq 0,05$ were considered statistically significant. Statistical analyzes were conducted through the Statistical PacKage for the Social Sciences (SPSS) software, version 21.0.

\section{RESULTS}

Considering the total participants (347), 4 (1.1\%) were considered frail, 163 (47\%) pre-frail and 180 (51.9\%) non-frail (Table 1).

Table 1 - Frequency distribution of physical frailty in elderly drivers of motor vehicles, city of Curitiba, Paraná State, Brazil, 2016

\begin{tabular}{lc}
\hline Frailty classification & Frequency $\mathbf{n}(\mathbf{\%})$ \\
\hline Non-frail & $180(51.9)$ \\
Pre-frail & $163(47.0)$ \\
Frail & $4(1.1)$ \\
Total & $347(100.0)$ \\
\hline
\end{tabular}

Table 2 - Distribution of personal, clinical and driving characteristics of the non-frail elderlies, city of Curitiba, Paraná State, Brazil, 2016

\begin{tabular}{lcc}
\hline Variables & Categories & $\mathbf{n}(\mathbf{\%})$ \\
\hline Sex & Male & $129(71.7)$ \\
Education & Female & $51(28.3)$ \\
& $\begin{array}{c}\text { Reads and writes } \\
\text { Pre-school }\end{array}$ & $1(0.6)$ \\
& High School & $41(22.7)$ \\
Une of medicines & Undergraduate Certificate & $75(41.7)$ \\
& Yes & $119(66.1)$ \\
Use of glasses to drive & No & $61(33.9)$ \\
& Yes & $100(55.6)$ \\
Drives during the night & No & $80(44.4)$ \\
Drives during the day & Yes & $125(69.4)$ \\
& No & $55(30.6)$ \\
Drives in the city centre & Yes & $177(98.3)$ \\
& No & $3(1.7)$ \\
Drives in highways & Yes & $160(88.9)$ \\
& No & $20(11.1)$ \\
Traffic accident after being 60 & Yes & $139(77.2)$ \\
& No & $41(22.8)$ \\
& Yes & $9(5.0)$ \\
& No & $171(95.0)$ \\
& &
\end{tabular}


Those classified as non-frail presented an average age of 65.91 \pm 55.6 years old. We found predominance of males $(n=129$; $71.7 \%)$, higher education level $(n=75 ; 41.7 \%)$, use of medicines $(n=119 ; 66.1 \%)$, use of glasses to drive $(n=100 ; 55.6 \%)$ and the report of not having experienced a traffic accident after being $60(n=171 ; 95.0 \%)$. As to displacement profile, 125 elderlies $(69.4 \%)$ would drive during the night, 160 (88.9\%) in the city centre and $139(77.2 \%)$ in highways (Table 2).

Table 3 shows that among the elderlies classified as non-frail, there is prevalence of the condition "capable with restriction" $(\mathrm{n}=121 ; 67.3 \%)$ as a result of the test for driving. No significantly statistic association was found between the condition of physical non-frailty and the results of the physical and mental tests for driving conducted by the traffic agency $(p=0.577)$.

Table 3 - Link between non-frail elderly drivers to the final result of the physical and mental driving test, city of Curitiba, Paraná State, Brazil, 2016

\begin{tabular}{lcccc}
\hline \multirow{2}{*}{ Test Result } & \multicolumn{2}{c}{ Non-frail } & Total (\%) & $\begin{array}{c}\boldsymbol{p} \\
\text { value }\end{array}$ \\
& Yes (\%) & No* (\%) & & \\
\hline Capable & $48(26.7)$ & $37(22.2)$ & $85(24.5)$ & \\
Capable with restriction & $121(67.2)$ & $117(70.0)$ & $238(68.5)$ & \\
Temporarily uncapable & $11(6.1)$ & $13(7.8)$ & $24(7.0)$ & 0.557 \\
Total & $180(51.8)$ & $167(48.2)$ & $347(100.0)$ & \\
\hline
\end{tabular}

Note: *it includes frail and pre-frail elderly drivers.

\section{DISCUSSION}

The prevalence of the non-frail elderlies was higher than when compared to the results of national studies involving those in the community. The survey FIBRA (Frailty of Brazilian Elderlies) carried out with 3.413 elderlies from seven Brazilian cities, identified the frailty conditions in relation to the sociodemographic, health, cognition, functional and psychosocial variables. Researchers have found a lower percentage of non-frail elderlies of approximately $39.1 \% \quad(n=1.335)$ (16). Another study examined the association between the Physical Frailty Syndrome and sociodemographic and clinic characteristics in 203 elderly users of the primary care of Curitiba City/PR (Brazil). Results have also shown reduced percentage of non-frail, totalling $24.1 \%(n=49)^{(17)}$.

International studies on the prevalence of non-frail elderly people are corroborated by this survey. Cross-sectional research in an urban district of Malaysia evaluated the frailty syndrome in 789 elderly people (age $\geq 60$ years old), living in the community. Those classified as non-frail were $26.6 \%{ }^{(18)}$. In the US, the multicentre longitudinal population study with 7,439 elderly found $39.2 \%$ non-frail people. In Australia, the result of a longitudinal population study with 2,087 elderly people showed $33.5 \%$ of non-frail.

The high percentage of non-frail elderlies in the current study is due to their clinic characteristics and to why they are taken to clinics, that is, the obtaining of their National Driver's License. For this end, these elderlies must be independent.
Therefore, non-frail. On the other hand, those who looked for clinics to renew their license was low, equivalent to $1.2 \%$.

In the present study, the elderlies presented an average age of $65.91 \pm 55.6$ years old. Studies show that age, itself, is not considered a risk factor for driving a motor vehicle. In the US, a survey compared the performance of 88 elderlies divided into 2 age groups: one from 80-87 and another from 90-97. The results pointed no substantial differences regarding both groups performances, suggesting that age is not a risk factor for the act of driving ${ }^{(21)}$.

The same occurred when a group of elderlies was compared to a group of young people, according to a study conducted in Canada, which aimed to assess the physiological responses to the act of driving. In this study, a group of 5 elderly people with an average age of 74.6 years old and a group of 5 young people aging 30 underwent cognitive assessment and road tests. The results have shown that the group of elderlies scored lower points on the cognitive tests, when compared to the group of young people. Despite that, the performance on the driving tests was equal for both ${ }^{(22)}$.

A study of literature review, covering the European Union, has shown that chronological age is not an isolated risk factor for traffic safety. However, this factor is still widely accepted as a tool to evaluate the performance of elderly drivers ${ }^{(23)}$. If we consider aging as a heterogeneous phenomenon, age may not be the best parameter to evaluate the ability of driving. It is still necessary to evaluate elderly drivers in some way, preferably through assertive tests. The evaluation of physical frailty may be an option, especially when the purpose is to measure the physical dimension they have.

In Brazil, age is not a determinant factor to evaluate elderly drivers, although it is mandatory for them to renew their Driver's License more often from the age of 65 . The Resolution of CONTRAN no 007/98 implemented medical examinations to this renewal and determined a new evaluation from 5 to 5 years for all drivers. From the age of 65 , medical examinations must be performed every 3 years. From the age of 80 , these examinations for renewal become annual ${ }^{(24)}$. In Europe, the steps to renew the National Driver's License and the validity of the document depends on each country ${ }^{(23)}$. We have not found records on categorization, such as capable, capable with restriction or uncapable in other countries. This makes this type of evaluation heterogeneous and difficult to compare.

Most of the non-frailty elderlies do not wear glasses. Visual impairment to drive is strictly connected to ophthalmic pathologies and age, which tend to cause ocular alterations like the diminution of a person's visual acuity and loss of the visual field. Pre-existing comorbidities can speed up these changes. These factors may lead to misjudgements regarding the distance and speed of the vehicle ahead or an erroneous interpretation of the traffic signalling ${ }^{(25)}$.

It is of utter importance to evaluate the vision of drivers in the aptitude test to drive. This factor is not part of the physical frailty evaluation. The need for glasses placed most of the elderlies in the group of capable drivers with restrictions. We did not expect this fact when we proposed crossing the variables (vehicular driving aptitude and frailty). At first, we expected to 
find out that most of the non-frail elderlies were capable to drive and the most of the pre-frail were capable with restrictions. This conclusion may explain why there was no significantly statistic association among the variables cited $(p=0.557)$.

There is only a small difference in the performance of elderlies in the tests of driving abilities when comparing the non-frail group to the group with frailty condition. This does not explain the association either. The difference of capable, non-frail elderlies was of $4.5 \%$ in relation to those capable with frailty condition. This difference is even smaller when comparing the other groups: elderlies with frailty condition presented values of only $2.8 \%$ and $1.7 \%$ higher than the categories capable with restriction and temporarily uncapable, respectively, when compared to those non-frail.

The displacement profile of non-frail elderlies is of being more cautious in risk-involving situations. Elderlies who reported to drive in good conditions, such as during the day, were $98.3 \%$. Besides that, $30.6 \%$ reported not to drive during the night, $22.8 \%$ in highways and $11.1 \%$ in the city centre.

The results are in accordance with those of the Center for Disease Control and Prevention (CDC), from 2001-2003 found through phone surveys (9.684 people were interviewed). The study's goal was to describe driving patterns of older adults, including driving restrictions and motor vehicles accidents. It was proved that over the years, elderlies tend to drive less often, for shorter distances and avoid to drive during the night and in the rush-hour ${ }^{(26)}$.

The pattern of elderlies drivers may justify the fact that only $5 \%$ have been involved in traffic accidents after 60 years old. Furthermore, the study at present aimed at evaluating nonfrail elderly drivers, and this condition can determine a low accident rate. The accidents at hand were reported by them before their physical and mental aptitude tests. This may lead to information left out, which could influence the decision of the medical expert.

A study conducted with 2.463 Brazilian elderlies proved that $20.2 \%$ of them had already been in a traffic accident and the victims were mostly (55.4\%) drivers. In the city of Curitiba, a crosssectional study obtained significantly statistic relation between traffic accidents and physical frailty $(p=0.0165)$. It showed that $90 \%$ of the reported accidents occurred to pre-frail elderlies ${ }^{(28)}$.

\section{Limitations and contributions to the nursing field}

The study's limitations (possible changes in outcomes) refer to the self-reported questions by the elderlies (evaluation of some frailty phenotype markers, clinical and driving variables). Since it is a cross-sectional study, it has not allowed us to prove causes and consequences among the variables. It was also carried out in only one city of the country.

This is an unprecedented study in nursing and it highlights an essential field for the performance of gerontological nursing. The results provide support for further studies aimed at a safer traffic environment.

\section{CONCLUSION}

Most of the elderlies who underwent physical and mental aptitude tests to drive motor vehicles are non-frail. The prevalence is substantial when compared to other studies that have investigated elderlies from the community.

There was no expressive association between the aptitude tests and physical frailty. Nevertheless, tracking frailty subsidizes preventive interventions, which seek to interfere positively in the act of driving.

The absence of physical frailty does not necessarily point out that the elderly is able to drive motor vehicles. The capable with restriction condition is primarily connected to the use of corrective lenses; the temporarily capable to the altered clinical condition. These parameters were not evaluated by the physical frailty phenotype. The isolated evaluation, upon the physical frailty phenotype, is insufficient to determine the physical aptitude of elderlies. It is therefore necessary to conduct more tests.

\section{FUNDING}

Coordination of Improvement of Higher Level Personnel (Coordenação de Aperfeiçoamento de Pessoal de Nível Superior-CAPES) and Araucária Foundation of Support to the Scientific and Technological Development of the State of Paraná (Fundação Araucária de Apoio ao Desenvolvimento Científico e Tecnológico do Estado do Paraná - Notice 09/2015, protocol 45784).

\section{REFERENCES}

1. Federação Nacional das Associações de DETRAN. Segurança no trânsito para a terceira idade[Internet]. 2013[cited 2017 Apr 08]. Available from: http://fenasdetran.com/noticia/seguranca-no-transito-para-a-terceira-idade

2. Pinheiro H. Veja o perfil dos motoristas de seu Estado. Jornal do Carro [Internet]. 2015. [cited 2016 Aug 20]. Available from: http:// www.estadao.com.br/jornal-do-carro/noticias/carros, veja-o-perfil-dos-motoristas-de-seu-estado,25282,0.htm

3. Brasil. Departamento de Trânsito do Paraná (DETRAN). Anuário Estatístico 2015 [Internet]. 2015. [cited 2016 Oct 12]. Available from: http://www.detran.pr.gov.br/arquivos/File/estatisticasdetransito/anuario/Anuario15.pdf

4. Brasil. Instituto de Pesquisa e Planejamento Urbano de Curitiba (IPPUC). Trânsito[Internet]. [cited 2016 Feb 03]. Available from: http://www.ippuc.org.br

5. Chihuri S, Mielenz TJ, DiMaggio CJ, Betz ME, DiGuiseppi C, Jones VC, et al. Driving cessation and health outcomes in older adults. J Am Geriatr Soc[Internet]. 2016 [cited 2016 May 2];64(2):332-41. Available from: http://onlinelibrary.wiley.com/doi/10.1111/ jgs.13931/abstract 
6. Cesari M, Prince M, Thiyagarajan JA, Carvalho IA, Bernabei R, Chan P, et al. Frailty: an emerging public health priority. J Am Med Dir Assoc[Internet]. 2016[cited 2016 May Jul];17(3):1-5. Available from: http://dx.doi.org/10.1016/j.jamda.2015.12.016

7. Gu D, Yang F, Sautter J. Socioeconomic status as a moderator between frailty and mortality at old ages. BMC Geriatrics [Internet]. 2016[cited 2016 Aug 9];16:151. Available from: http://bmcgeriatr.biomedcentral.com/articles/10.1186/s12877-016-0322-2.

8. Morley JE, Vellas B, Van Kan GA, Anker SD, Bauer JM, Bernabei R, et al. Frailty Consensus: a call to action. J Am Med Dir Assoc [Internet]. 2013 [cited 2016 Apr 24];14(6):392-7. Available from: http://dx.doi.org/10.1016/j.jamda.2013.03.022

9. Fried LP, Tangen CM, Walston J, Newman AB, Hirsch C, Gottdiener J, et al. Frailty in older adults: evidence for a phenotype. J Gerontol A Biol Sci Med Sci[Internet]. 2001[cited 2016 Feb 14];56(3):M146-56. Available from: https://doi.org/10.1093/ gerona/56.3.M146

10. Dickerson AE, Meuel DB, Ridenour CD, Cooper K. Assessment tools predicting fitness to drive in older adults: a systematic review. Am J Occup Ther[Internet]. 2014 [cited 2017 Apr 08];68(6):670-80. Available from: http://ajot.aota.org/article. aspx?articleid $=1934883$

11. Brasil. Conselho Nacional de Saúde (CNS). Ministério da Saúde. Resolução n. ${ }^{\circ}$ 466, de 12 de dezembro de 2012. Diretrizes e normas regulamentadoras de pesquisa envolvendo seres humanos. Brasília [Internet]. 2012[cited 2016 Feb 14]. Available from: http://bvsms.saude.gov.br/bvs/saudelegis/cns/2013/res0466_12_12_2012.html

12. Bertolucci PH, Brucki SM, Campacci SR, Juliano Y. The Mini-Mental State Examination in a general population: impact of educational status. Arq Neuropsiquiatria[Internet]. 1994 [cited 2017 Apr 08];52(1):1-7. Available from: http://dx.doi.org/10.1590/ S0004-282X1994000100001

13. Brasil. Departamento Estadual de Trânsito. Portaria $n^{0}$ 303, de 03 de junho de 2015. Edital de credenciamento[Internet]. 2015[cited 2016 Mar 14]. Available from: http://www.detran.pr.gov/arquivos/File/legislacao/atosdodiretorgeral/2015/303_Edital_Credenc_ Clinicas.pdf

14. Lustosa LP, Pereira DS, Dias RC, Britto RR, Parentoni AN, Pereira LSM. Tradução e adaptação transcultural do Minnesota Leisure Time Activities Questionnaire em idosos. Geriatr Gerontol[Internet]. 2011[cited 2017 Apr 08];5(2):57-65. Available from: www. ggaging.com/export-pdf/245/v5n2a03.pdf

15. Brasil. Conselho Nacional de Trânsito (CONTRAN). Resolução n ${ }^{\circ}$ 425, de 27 de novembro de 2012. Dispõe sobre o exame de aptidão física e mental, a avaliação psicológica e o credenciamento das entidades públicas e privadas de que tratam o art. 147, I e $\S \S 1^{\circ}$ a $4^{\circ}$ e o art. 148 do Código de Trânsito Brasileiro[Internet]. Diário Oficial da União, Brasilia, DF: 10/12/2012[cited 2016 Feb 14]. Available from: http://www.denatran.gov.br/download/Resolucoes/(Resolu\%C3\%A7\%C3\%A3o\% 20425.-1).pdf

16. Neri AL, Yassuda MS, Araújo LF, Eulálio MC, Cabral BE, Siqueira MEC, et al. Methodology and social, demographic, cognitive, and frailty profiles of community-dwelling elderly from seven Brazilian cities: the FIBRA Study. Cad Saúde Pública [Internet]. 2013 [cited 2016 Jun 10];29(4):778-92. Available from: http://dx.doi.org/10.1590/S0102-311X2013000400015

17. Lenardt MH, Carneiro NHK, Binotto MA, Setoguchi LS, Cechinel C. Relação entre fragilidade física e características sociodemográficas e clinicas de idosos. Esc Anna Nery Rev Enferm [Internet]. 2015 [cited 2016 Jul 05];19(4):585-92. Available from: http://dx.doi.org/10.5935/1414-8145.20150078

18. Sathasivam J, Kamaruzzaman SB, Hairi F, Nq CW, Chinna K. Frail elders in an urban district setting in malaysia: multidimensional frailty and its correlates. Asia Pac J Public Health [Internet]. 2015 [cited 2016 May 25];27(8-suppl):52S-61S. Available from: http:// journals.sagepub.com/doi/10.1177/1010539515583332

19. Bandeen-Roche K, Seplaki CL, Huang J, Buta B, Kalvani RR, Varadhan R, et al. Frailty in older adults: a nationally representative profile in the United States. J Gerontol A Biol Sci Med Sci[Internet]. 2015 [cited 2016 Jun 22];70(11):1427-34. Available from: https://doi.org/10.1093/gerona/glv133

20. Widagdo IS, Pratt N, Russell M, Roughead EE. Predictive performance of four frailty measures in an older Australian population. Age Ageing[Internet]. 2015 [cited 2016 Jun 11];44(6):967-72. Available from: https://doi.org/10.1093/ageing/afv144

21. Hollis AM, Duncanson H, Kapust LR, Xi PM, O'Connor MG. Validity of the mini-mental state examination and the montreal cognitive assessment in the prediction of driving test outcome. J Am Geriatr Soc[Internet]. 2015 [cited 2016 Aug 03];63(5):988-92. Available from: http://dx.doi.org/10.1111/jgs.13384

22. Koppel SN, Charlton JL, Fildes BN. Distraction and the older driver. In: Regan MA, Lee, JD, Young KL. (eds.). Driver distraction: theory, effects and mitigation. Florida, USA: CRC Press, 2009.

23. Siren A, Haustein S. Driving licences and medical screening in old age: review of literature and European licensing policies. J Transport Health [Internet]. 2015 [cited 2016 Jul 15];2(1):68-78. Available from: http://dx.doi.org/10.1016/j.jth.2014.09.003

24. Brasil. Conselho Nacional de Trânsito - CONTRAN. Resolução nº 007/98. Modifica dispositivos das Resoluções 734/89, 765/93 e 828/97, que tratam da formação de condutores e dos procedimentos para a habilitação [Internet]. 1998 [cited 2016 Jul 15]. Available from: http://www.denatran.gov.br/resolucoes.htm

25. Almeida MHM, Caromano FA, Ribeiro SS, Batista MCP. Programa de orientação com ênfase em práticas de autocuidade para motoristas idosos. Rev Bras Geriatr Gerontol[Internet]. 2016 [cited 2016 Jul 25];19(2):303-11. Available from: http://dx.doi. org/10.1590/1809-98232016019.140192

26. Betz ME, Lowenstein S. Driving patterns of older adults: results from the Second Injury Control and Risk Survey. J Am Geriatr 
Soc[Internet]. 2010 [cited 2016 Jul 08];58(10):1931-5. Available from: http://dx.doi.org/10.1111/j.1532-5415.2010.03010.x

27. Freitas MG, Bonolo PF, Moraes EN, Machado CJ. Idosos atendidos em serviços de urgência no Brasil: um estudo para vítimas de quedas e de acidentes de trânsito. Ciênc Saúde Colet[Internet]. 2015 [cited 2016 Nov 20];20(3):701-12. Available from: http:// dx.doi.org/10.1590/1413-81232015203.19582014

28. Lenardt MH, Cechinel C, Binotto MA, Carneiro NHK, Lourenço TM. Relação entre fragilidade física e fatores sociodemográficos e clínicos dos idosos que realizam teste para habilitação veicular. Esc Anna Nery Rev Enferm[Internet]. 2016 [cited 2016 Nov 08];20(4). Available from: http://dx.doi.org/10.5935/1414-8145.20160097 